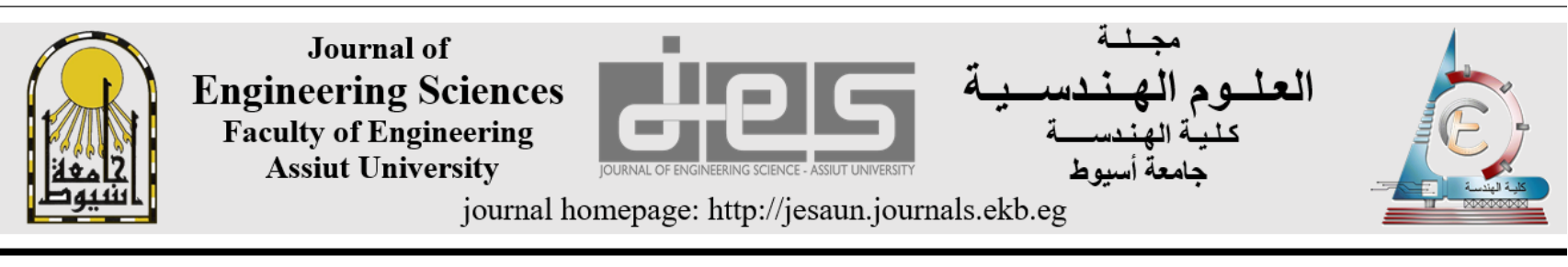

\title{
Highlights on the Beneficiation Trials of the Egyptian Phosphate Ores
}

Sherein Ahmed M.E. Rizk ${ }^{1}$

\section{Keywords}

Beneficiation of phosphate ore - Nile Valley Egyptian phosphate ore - Red Sea Egyptian phosphate ore Abu Tartur Egyptian phosphate ore.

\begin{abstract}
Most deposits which can be mined and processed economically to produce a concentrate with a grade of about 28-38\% P2O5 are considered commercial phosphate deposits. Because of the increasing world demand, the grade of a great portion of the mined phosphate deposits is declined and many low-grade phosphate deposits became economically mineable. Methods and techniques used in the processing of ore are depending on its grade, type and quantity of gangues associated with the phosphate mineral. Phosphate deposits in Egypt occur with large quantities in the Nile valley, red sea, and the new valley areas. Therefore, the main objective of this review is to shed some light on the locations, reserves, and the beneficiation trials of the different localities of the Egyptian phosphate ores, with focusing on water conservation in the dressing plants and positive uses of solid wastes. It is recommended to use the bio-flotation, column flotation, and the new types of reagents, as recent trends to upgrade the Egyptian phosphate ores. It is also advised to pay attention towards the recovery of phosphate from its slimes.
\end{abstract}

\section{Introduction}

Phosphate rocks are vital non-renewable resources and are essential components in agricultural fertilizers and phosphorous-based chemicals [1-4]. About 95\% of the phosphate produced worldwide is consumed in the fertilizer industry [5-6]. Phosphate deposits can be divided into three groups (i) sea sediments, (ii) igneous and (iii) biogenetic deposits [7]. The distribution of phosphate resources in the world is approximated as follows: 75\% from sedimentary marine deposits, 15-20\% from igneous, metamorphic and weathered deposits, and 2-3\% from biogenic sources [5-8]. A large proportion of the world's phosphate reserves are sedimentary deposits containing a considerable amount of carbonate minerals. In terms of quality and $\mathrm{P}_{2} \mathrm{O}_{5}$ grade, phosphate can be divided into three groups: low - grade ores $\left(12-16 \% \mathrm{P}_{2} \mathrm{O}_{5}\right.$, intermediate-grade ores $\left(17-25 \% \mathrm{P}_{2} \mathrm{O}_{5}\right)$ and highgrade ores (26-35\% $\mathrm{P}_{2} \mathrm{O}_{5}$ ). Deposits containing of $28-38 \% \mathrm{P}_{2} \mathrm{O}_{5}$ are considered commercial grade deposits and have high economic value to mine and process [9].

${ }^{1}$ Faculty of Engineering, Beni-Suef University ( shereinahmedrizk2020@ gmail.com ) 
Phosphate ore processing techniques are depending on the type of phosphate minerals and associated gangue. The most abundant phosphate deposits are the marine sediments, which contain variable amounts of carbonates (calcite or dolomite) and silicates. Flotation is used successfully in upgrading siliceous ores, whereas scrubbing and desliming techniques are used to remove silicates (clays). The calcareous type of phosphate ore is extremely difficult to concentrate via flotation because of the similar physicochemical surface characteristics of the main constituents, i.e., carbonates and phosphates [10-11]. Calcination is used for ores that have low or average carbonate content [12]. Flotation can be applied to high carbonate content ores. Over $60 \%$ of the commercial phosphate in the world is produced through flotation [5].

In 2012, the world phosphate production reached $217 \mathrm{Mt}$, out of which $209 \mathrm{Mt}$ were produced by eighteen major phosphate producing countries (countries whose production exceeds 1 million tons per year). Egypt is the seventh country in this descending order [1-2]. There is a need for exploiting the ore reserves to relieve the dependency on importation. In Egypt, there have been substantial works in the beneficiation of the different localities of phosphate ore. Therefore, the main aim of this review article is to shed some light on the beneficiation trials of the Egyptian phosphate ores, with more stress on the freshwater consumption in the dressing plants, positive uses of solid wastes, and solid as well as liquid regaining from tailings. Phosphate deposits in Egypt occur in the following three regions $[1,13]$ :

- The Nile valley between Edfu and Qena (Sebaiya East and West).

- The red sea areas (Safaga, El-Hamrawein and El Quseir).

- The New valley at Abu Tartur.

Figure (1) shows a map of the major phosphate deposits in Egypt [13].



Fig. (1) A map of the major phosphate deposits in Egypt [13] 


\section{Nile Valley Phosphate Ore}

\subsection{Situation and Reserves of Nile Valley Phosphate ore}

Phosphate rock from the Nile Valley deposits is worked by El-Nasr phosphate Co. at Sebaiya East and Abu Zaabal Fertilizers and Chemical Co. (for the time being) produced phosphate from Sebaiya West. These deposits are situated on both banks of Nile Valley, some $70 \mathrm{~km}$ South of Luxor between the towns of Isna and Edfu. They extend over an area of about $25 \mathrm{~km}^{2}$, which are bound by latitude $25^{\circ} 05^{\prime}-25^{\circ} 15^{\prime} \mathrm{N}$ and longitudes $32^{\circ} 40^{\prime}-33^{\circ} 00^{\prime} \mathrm{E}$. These phosphate deposits are a part of a vast upper cretaceous (Comparian Maestricht) phosphate province, which extends along an ancient shelf of the African platform from the Red Sea via the Nile Valley in to the Lybian district. This platform type deposit consists of near horizontal, only little distributed phosphate beds at the beds of an upper Cretaceous Eocene Marine sedimentary sequence [14].

El-Nasr phosphate company has reserves around 22 million tons in Sebaiya East and produces 0.5 million types of phosphate grading $23 \% \mathrm{P}_{2} \mathrm{O}_{5}$. Beginning in 1989, El Nasr purchased new mining equipment and built a new 250 tph beneficiation plant for phosphate washing. Production in 1993/1994 totaled 78,000 ton of concentrate (of a 29\% $\mathrm{P}_{2} \mathrm{O}_{5}$ ) product (International Report of Behre Dolhear and Overseas Bechtel Co., 1995) [13]. In the last few years, new reserves of better grade have been discovered. Abu Zaabal Fertilizers and Chemical Co. worked the deposit in Sebaiya West and installed a new beneficiation plant at the end of 1992 to increase its phosphate production capacity to about $1,600,000$ types. The produced phosphate is transferred to its own fertilizer production plant at Cairo area [15].

\subsection{Beneficiation Technologies of Nile Valley Phosphate Ores}

\subsubsection{Beneficiation Technology of Sebaiya West Phosphate}

The phosphate beneficiation plants of Sebaiya West, Egypt, of one million ton/year capacity consists of two sections:

- The crushing and scrubbing plant for treatment of friable phosphate ores.

- The milling and flotation plant handles hard and massive siliceous phosphate ores as well as fines produced by the first plant. The beneficiation plants receive phosphate ores from two mines at Sebaiya West. The ore from both mines consists of two fractions, a friable part and a massive one. The crushing and scrubbing plant can successfully handle the beneficiation of friable phosphate ore. In the crushing and scrubbing plant, the phosphate ore is initially screened on $60 \mathrm{~mm}$ screen and the oversize is crushed by a jaw crusher to $-10 \mathrm{~mm}$. To control the degree of $-0.5 \mathrm{~mm}$ fines to about $15 \%$ weight in the run of mine (ROM), the crushed ore is passed through a $30 \mathrm{~mm}$ screen. The $+30 \mathrm{~mm}$ oversize is directed through belt conveyor, to the plant as a feed to the rotary scrubber, which has a trommel screen of $30 \mathrm{~mm}$ Fig. (2) [13]. The scrubbed product is screened through 2 sets of Mogensen sizers. The top screen of the sizer is $25 \mathrm{~mm}$, followed by screens of $14,10,5,2$ and $0.9 \mathrm{~mm}$ at the bottom. The $+25 \mathrm{~mm}$ oversize is crushed by a standard cone crusher and is returned to the rotary scrubber. The size fraction $25+0.9 \mathrm{~mm}$ is stock piled as an oversize rod mill feed in the milling and flotation plant.

The size fraction below $0.9 \mathrm{~mm}$ is classified by a spiral classifier to separate the slimes from the scrubber product. The underflow of the classifier is returned for further upgrading by hydro cyclones, where more slimes can be separated. The underflow fraction of the hydro cyclones is dewatered through a dewatering screen. The screen oversize is considered a final product if it's a 
high grade, or it may be directed to the thickener. The product is subjected to flotation. On the other hand, the second plant (milling and flotation) is designed for upgrading the massive ores, Fig. (3). This plant receives two types of phosphate feed: the slimes (thickener underflow and the coarse massive) phosphate feed $(-25+0.9 \mathrm{~mm})$ from the first (crushing and scrubbing) plant. The slimes are directly supplied to a fine section of the flotation plant. Meanwhile, the coarse feed $(-25+0.9 \mathrm{~mm})$ is ground in a rod mill to about $-10 \mathrm{~mm}$, and then the ground product is classified in a spiral classifier, where the underflow is further reground in a ball mill. The latter is connected, in a closed circuit, to a group of hydro cyclones to recycle the underflow to the ball mill for further grinding. The overflow of both the classifier and hydro cyclones, together with (or without) the slimes of the first plant, are collected for further classification in a second group of hydro cyclones. The underflow of the latter is directed to the flotation cells, while the overflow, together with that of secondary hydro cyclones, feed a group of tertiary hydro cyclones. The overflow (slimes of the latter group of hydro cyclones) is directed to a tailing's thickener, whereas the underflow product feeds a hydro cyclone separator, Then the product of which is directed to a tailing's thickener, whereas the underflow product feeds a hydro separator, the product of which is directed to the fine section of flotation cells. The plant has two groups of flotation cells. The first is termed the sand flotation section for treating coarse particles whereas the other, devoted for flotation of fine phosphate, is known as fine section. Each of these groups consists of rougher cells followed by cleaning stages. The flotation process is carried out at $\mathrm{pH}$ 9-10 using sodium silicate as a depressant for silica and fatty acid (oleic acid or its substitute e.g., the bran oil) as a collector for phosphate. Fig. (3) shows a simple flowsheet for such milling and flotation plant.



Fig. (2) Flowsheet of crushing and scrubbing plant [13]

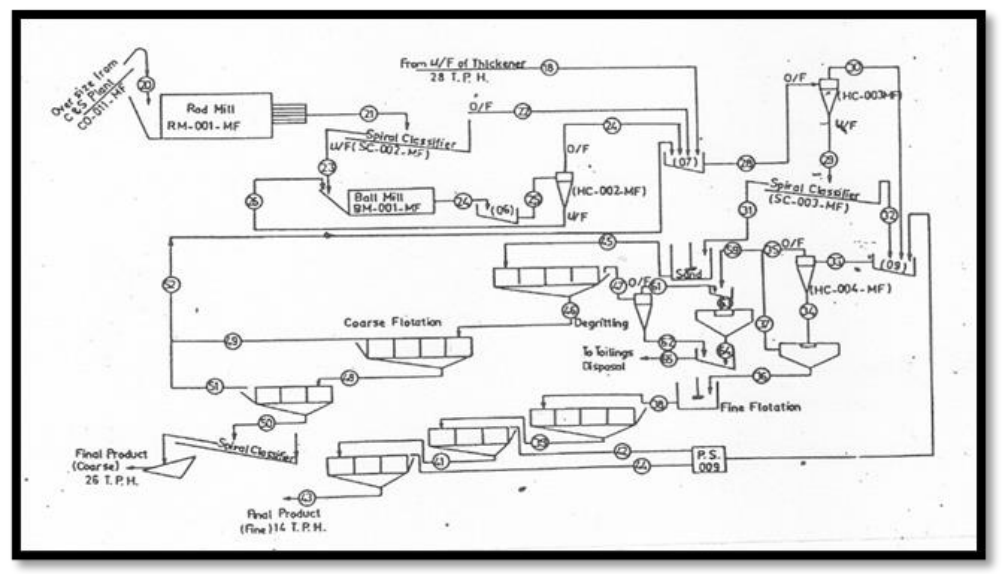

Fig. (3) Milling and flotation plant of Sibiya West phosphate [13] 
However, these beneficiation plants suffer from many technical problems, especially, 1) The low grade and recovery of concentrate 2) The plants are designed to treat only siliceous phosphate ores (of the Northern mine) but not the siliceous - calcareous phosphates of the Southern mine [16]. Trials to improve the grade of concentrates from the existing flotation plant as well as the amenability of flotation of both carbonates and silica instead of silica only are investigated at the Central Metallurgical Research and Development Institute (CMRDI) [17-18]. For example, operating the crushing and scrubber plant at its maximum capacity (268 T.P.H) caused turbidity for the main thickener due to the tremendous number of slimes generated by the scrubber [16]. CMRDI authorities suggested the addition of hydro cyclone before the thickener to recover the valuable fine phosphate, which are dumped as slimes together with optimizing the type and dosage of flocculant added to the thickener $[17,19,20]$.

\subsubsection{Beneficiation Technology of Sebaiya East Phosphate}

The Nile Valley phosphate deposits at Sebaiya East are clay-siliceous ores that necessitate the use of washing technique. For this reason, The Sebaiya East new plant includes only washing technique. The ore is enriched from below $22 \%$ to $28 \% \mathrm{P}_{2} \mathrm{O}_{5}$ with about $65 \% \mathrm{P}_{2} \mathrm{O}_{5}$ recovery. The $\mathrm{MgO}$ content of concentrates is low $(\sim 0.5 \%)$. During the last few years, El-Nasr phosphate Co. fortunately discovered a new locality in the same area of higher-grade ores that need only crushing and classification to produce concentrates of $30-31 \% \quad \mathrm{P}_{2} \mathrm{O}_{5}$. Such concentrates are currently exported. Figure (4) shows the Sebaiya East washing plant [21-22].



Fig. (4) Sebaiya - East Phosphate Washing Plant [21-22]

\subsection{Beneficiation Trials of Nile Valley Phosphate Ores}

Tarshan [23] used a lab-scale fluidized bed technique as a thermal treatment to upgrade El-Sebaiya intermediate- grade phosphate ores. This thermal treatment process included roasting and calcining. $\mathrm{He}$ studied the effect of some design and operating parameters on the upgrading of $\mathrm{P}_{2} \mathrm{O}_{5}$. The thermally treated phosphate rock was washed with water. This method raised the $\mathrm{P}_{2} \mathrm{O}_{5}$ content from 
$20 \%$ to about $30 \%$. However, it is costly. Youssef et al. [24] studied the amenability of calcareous Sebaiya East phosphate to upgrading using the calcination slaking method. Calcination at $850^{\circ} \mathrm{C}$ yielded a phosphate concentrate assaying $32.9 \% \mathrm{P}_{2} \mathrm{O}_{5}, 0.66 \% \mathrm{MgO}$.

Abd El Reihm [25] studied both fine waste of Sebaiya West phosphate ore and the ground ore to less than $0.106 \mathrm{~mm}$ by using the column flotation as a new technique. The column flotation of fine waste gave a concentrate assaying $25 \% \mathrm{P}_{2} \mathrm{O}_{5}$, and $15 \%$ insoluble residue with a recovery of about $52 \%$ from a feed assaying $18 \% \mathrm{P}_{2} \mathrm{O}_{5}$ and $24 \%$ insoluble residue. The results of column flotation of ore ground to $100 \%$ below $0.106 \mathrm{~mm}$ showed that the grade of the concentrate of such low-grade phosphate was improved to about $30.4 \% \mathrm{P}_{2} \mathrm{O}_{5}$ and $8.64 \%$ insoluble residue with a recovery of $70.24 \%$. This concentrate was better that obtained by using the conventional flotation technique.

A high-grade phosphate ore sample $\left(27.3 \% \mathrm{P}_{2} \mathrm{O}_{5}\right.$, and $\left.168 \mathrm{mg} / \mathrm{kg} \mathrm{U}\right)$ from Sebaiya East, Egypt, was subjected to a reverse single - stage flotation to separate carbonate from the phosphate sample by Ramadan [26]. A concentrate of $32.2 \% \mathrm{P}_{2} \mathrm{O}_{5}$ with recovery of $92.1 \%$ and $225 \mathrm{mg} / \mathrm{kg} \mathrm{U}$ was obtained. These results were achieved under the following optimum conditions: a $3.5 \mathrm{~kg} / \mathrm{t}$ collector dosage, a $5.8 \mathrm{pH}$, a $20 \mathrm{~L} / \mathrm{min}$ gas flow rate, and a $1000 \mathrm{rpm}$ agitation speed.

El-Nasr Phosphate Company, Egypt, is processing phosphate rock in El-Mahamid Beneficiation Plant (EMBP) to a rate of $250 \mathrm{t} / \mathrm{h}$. Water is used in this plant at the amount of $750 \mathrm{~m}^{3} / \mathrm{h}$. Most of the water appears as slime tailings which have to be disposed of. Negm and Emam [27] found that the surface impoundments were the most suitable methods of disposal. A site of large volume was chosen for this purpose. Disposal of ore dressing plant tailings is a major environmental problem, which is becoming more serious with the increasing exploitation of low-grade ores and deposits due to the depletion of rich ones [28]. Control of dust emitted from tailings requires that the surface of tailings dumps should be stabilized by physical or chemical means or by vegetation [29]. Disposal areas are sometimes subject to wind erosion, producing fugitive dust emission [30].

Numerous processes were applied on the phosphate tailings to minimize their negative environmental hazards. One of these is the biotechnology, which provides a novel solution to environmental problems. At the same time, the phosphorus values of the slimes can be recovered with the use of such a technique [31].

In Sebaiya (Egypt) phosphate companies (East and West of the River Nile), more than one and a half million tons of tailings are accumulated as slimes and solid wastes. The slimes portion represents about one-third of this amount with $\mathrm{P}_{2} \mathrm{O}_{5}$ content of 8-14\%, while the solid wastes represent the rest of this amount with $\mathrm{P}_{2} \mathrm{O}_{5}$ content of $18 \%$. These tailings, especially the slime, cause environmental problems [32]. positive use of making bricks using El-Sebaiya phosphate tailings was tried by Galal et al. [33]. It was found that, bricks with high qualities can be produced using these tailings. The compressive strength of the produced brick is higher than that of the Nile silt brick and water absorption is lower than that of the Nile silt brick. The amount of these wastes reached 8 million tons in 2012. Rizk [34] studied the amenability of using phosphate solid wastes in concrete production. The produced concrete was tested for mechanical properties according to the Egyptian code. The suitability of these wastes for road construction and as replacement soil under foundations was also confirmed. These wastes were also used in road curbs, concrete flower pots and concrete bricks.

On the other hand, Abuel kasem et al, [35] studied the upgrading of phosphate ore wastes of ElNasr mining company at Edfu. They suggested different alternatives of flow sheet which include crushing and grinding, attrition Ing, scrubbing and leaching processes. The results of these alternatives raised the $\mathrm{P}_{2} \mathrm{O}_{5} \%$ from 18.37 to 28.44 with a weight recovery of $59.87 \%$. In addition, the authors [36] made also an economic study to produce $190.000 \mathrm{tpa}$. This study illustrated that upgrading this number of wastes achieves 18 million LE per year. 


\section{Red Sea Phosphate Ore:}

\subsection{Situation and Reserves of Red Sea Phosphate Ore}

Red sea Phosphate Co. extracts phosphate from underground mines in the Red Sea area at Safaga, El-Hamrawein and Quseir. Figure (5) illustrates a location map of phosphate localities within the Red Sea region [1]. The deposits at Safaga area occur at Um-El Huetat, Jesslyn and Hogab, located 12 to $22 \mathrm{~km}$ in the land from the Red Sea. Deposits at Quseir are located between 10-30 km from the port of Quseir. There are various outcrops and the phosphate occurs above and below two thick beds of green clays and includes 10-15 m of phosphatic strata [14, 37]. The total output from these mines is estimated to be in the order of 300.000-400.000 type in 1989/1990 and about 450.000 type in 1993 [15].



Fig. (5) Location map of phosphate localities within the Red Sea region [1]

\subsection{Beneficiation Technology of Red Sea Phosphates}

Each ore deposit has its specific gangue mineral components, and that is why each of the Red Sea phosphate beneficiation plants has its own flow sheet. However, they all have a common washing section to free the clay, to some extent, the silica minerals. An exception is Safaga plant shown in Fig. (6) [21-22], where the treatment of rich ores is carried out by crushing and grinding [13]. Quseir Beneficiation Plant shown in Fig. (7) [21-22] applies only washing (in log. washers) and classification using seawater. Drying is carried out by the sun and fuel oil. The plant is simple, compact and efficient. The $\mathrm{P}_{2} \mathrm{O}_{5}$ is enriched to $28-29 \%$, with about $65 \%$ recovery. Due to the presence of high content of dolomite in Hamrawein phosphate ores, the Hamrawein Beneficiation Plant was designed to include both washing and calcination sections. The latter section was stopped as it was found impractical and inefficient [38]. The adjusted flowsheet of the Hamrawein beneficiation plant is shown in Fig. (8) [21-22]. In addition, the calcined products are not attractive to external market due to their low reactivity in downstream fertilizer processes.

Hamrawein phosphate ore with $\sim 22 \% \mathrm{P}_{2} \mathrm{O}_{5}$ is enriched to $\sim 29 \% \mathrm{P}_{2} \mathrm{O}_{5}$ at about $60 \% \mathrm{P}_{2} \mathrm{O}_{5}$ recovery. The products contain high $\mathrm{MgO}(\sim 5 \%)$ and chlorine (Clo $\sim 0.5 \%)$ contents since the seawater is used in washing. All the phosphate is exported for direct application markets [15]. 


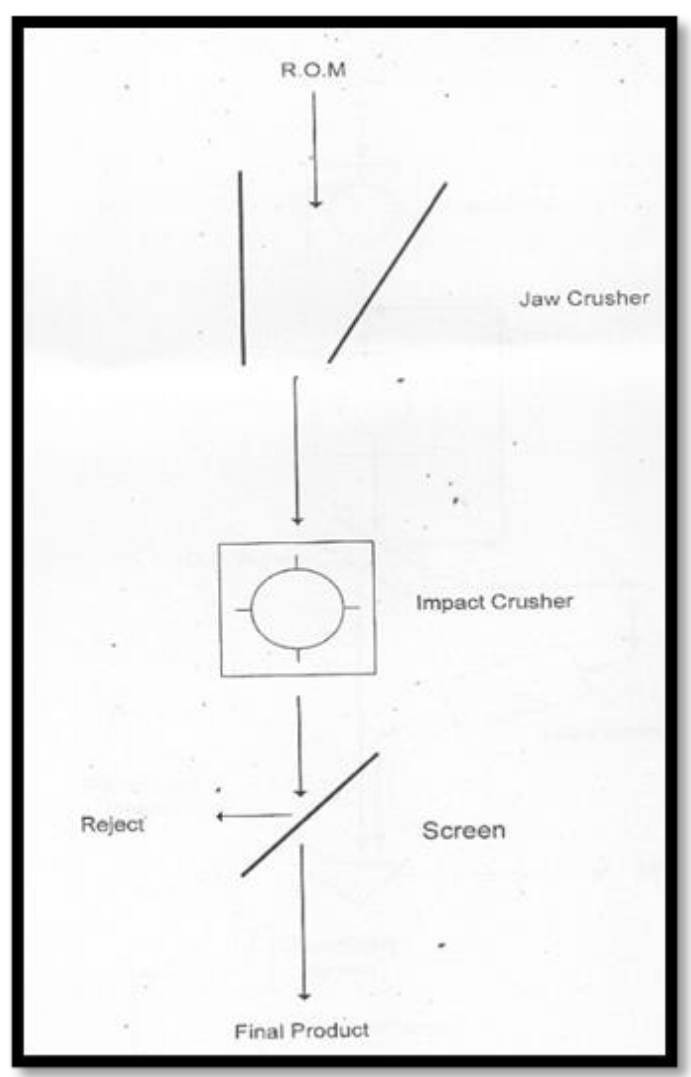

Fig. (6) Mohamed Rabah (Safaga) Phosphate Plant [21-22]

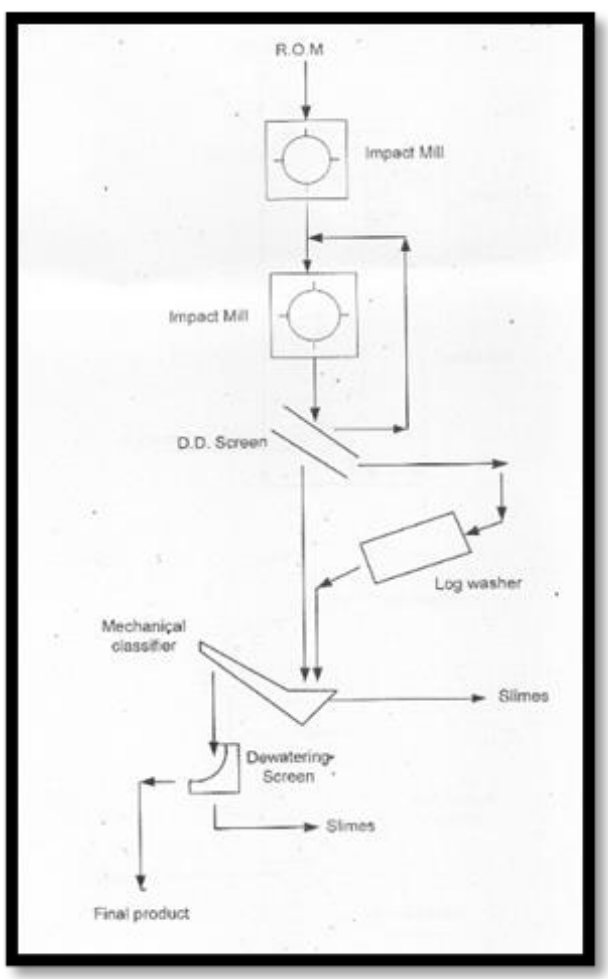

Fig. (7) Quseir Phosphate Preparation Plant [21-22] 


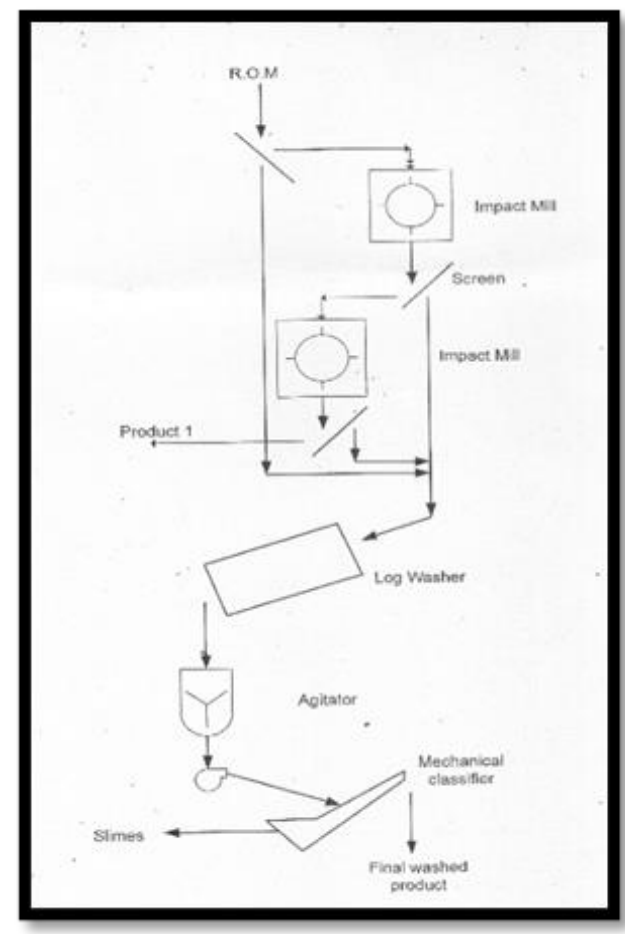

Fig. (8) Hamrawien Phosphate Preparation Plant [21-22].

\subsection{Beneficiation Trials of the Red Sea Phosphate Ores:}

The amenability of the Red Sea low-grade siliceous phosphate ores to upgrading was shown by Orphy et al. [39]. A stage flotation was recommended to give an optimum grade flotation concentrate, further upgrading being accomplished by calcination and washing. By applying the optimum conditions recommended, the authors obtained a phosphate concentrate assaying $31.1 \%$ $\mathrm{P}_{2} \mathrm{O}_{5}$ and $4.31 \%$ insoluble at a recovery of $79.47 \%$, from a flotation feed containing $18.2 \% \mathrm{P}_{2} \mathrm{O}_{5}$ and $41.9 \%$ insoluble. In the second part of this work [40] the authors show the possibility of floating silica from low grade siliceous phosphate ores by cationic collectors. The optimum results obtained in this investigation were compared with those of the Denver Equipment Co. ltd.

The amenability of dolomitic phosphate ore from Red Sea areas to upgrading by reverse anionic flotation was studied by Bebawy and Yousef [41]. At the optimum conditions selected, a concentrate assaying $32.2 \% \mathrm{P}_{2} \mathrm{O}_{5}, 1.03 \% \mathrm{MgO}$ and $3.17 \% \mathrm{SiO}_{2}$ at a recovery of $85.89 \% \mathrm{P}_{2} \mathrm{O}_{5}$ was obtained from a flotation feed containing $26.39 \% \mathrm{P}_{2} \mathrm{O}_{5}, 4.54 \% \mathrm{MgO}$ and $3.23 \% \mathrm{SiO}_{2}$.

The phosphate sample from the Red Sea phosphate company was enriched by flotation by Abdelrahman [42]. To separate apatite from carbonate, he used five reagent systems differed in regulator types. The regulator types were copper sulphate, Alum, caustic soda, caustic starch and copper sulphate and caustic soda. He concluded that the results of all systems have shown to be reasonable. Hence selection of the suitable one would be greatly affected by economic factors.

The amenability of low- grade calcareous phosphate ore of Um-Hammad area (Red Sea Phosphate) to upgrading by leaching with acetic acid solutions to increase the TCP content and reducing the calcium carbonates to an acceptable limit was investigated by Abdul-Majeed [43]. By applying the selected optimum conditions, a phosphate concentrate assaying $70.3 \%$ TCP, $4.4 \% \mathrm{CO}_{2}, 5.2 \%$ I.R., with $70 \%$ weight recovery was obtained from a leaching feed containing about $55 \%$ TCP, $12.3 \%$ $\mathrm{CO}_{2}, 4.4 \%$ I.R., without any expensive chemicals or energy required in conventional flotation and calcination methods. The results of this work are particularly important to produce phosphate 
fertilizers. Rizk [44] made an experimental comparative study between calcination and leaching of Um-Hammad area (Red Sea) low-grade phosphate ore. The study showed that the calcination process is more reasonable than leaching for upgrading the low-grade calcareous phosphate ore. Therefore, the author recommended using a cheap fuel, such as natural gas as a source of energy to reduce the calcination costs. Hamrawein area phosphate ore was studied using the flotation technique by Ramadan [45]. He achieved reasonable results.

An East Mediterranean phosphate sample was subjected to beneficiation by unsophisticated economic means by Suzan et al. [46]. The primary crushed sample was classified into three size fractions $(-22+11 \mathrm{~mm},-11+6.6 \mathrm{~mm},-6.6+3.2 \mathrm{~mm})$ without any milling and each size fraction was subjected to an integrated study of attrition scrubbing. Screening and classification on $2.3 \mathrm{~mm}$ and $0.071 \mathrm{~mm}$ sieves were sequentially introduced with the attrition process. The results showed that a global $\mathrm{P}_{2} \mathrm{O}_{5}$ of $-3.2+2.3 \mathrm{~mm}$ and $-2.3+0.071 \mathrm{~mm}$ size fraction was $28.72 \%$ with $52 \%$ recovery. $0.071 \mathrm{~mm}$ size fraction phosphor mud was treated by using the Falcon apparatus as a gravity method [47]. Therefore, the total recovery of $\mathrm{P}_{2} \mathrm{O}_{5}$ was raised from $52 \%$ to $89.16 \%$ with $\mathrm{P}_{2} \mathrm{O}_{5}$ content of $28.48 \%$.

Fine Red Sea phosphate $(<45 \mu \mathrm{m})$ characterized by low $\mathrm{P}_{2} \mathrm{O}_{5}(18.78 \%)$ content associated with gangue minerals such as Silica $\left(22.77 \% \mathrm{SiO}_{2}\right)$ and Carbonate $(2.01 \% \mathrm{MgO})$ was preconcentrated by gravity separation using Falcon apparatus by Yehia et al. [48]. The results of this preconcentration achieved a concentrate of $24.94 \% \mathrm{P}_{2} \mathrm{O}_{5}$ with $63.37 \%$ recovery $1.46 \% \mathrm{MgO}$ and $10.54 \% \mathrm{SiO}_{2}$. The gravity concentrate was subjected to reverse flotation using a bench scale column. Oleic acid was used as a carbonate gangue collector and amylase enzyme was used as a phosphate depressant. Phosphor concentrate assaying $27.85 \% \mathrm{P}_{2} \mathrm{O}_{5}$ with $55.45 \%$ recovery, $0.61 \% \mathrm{MgO}$, and $13.14 \% \mathrm{SiO}_{2}$ was finally obtained.

Due to the shortage of fresh water in the Middle East, seawater has been used as an alternative in flotation beneficiation [49-50]. The flotation process requires about $7 \mathrm{~m}^{3}$ of water/mt ore [49]. The effect of seawater cations and anions on the flotation of four important minerals was studied by Yousef et al. [49]. Both fresh water and simulated sea water were used as well as natural seawater. The main harmful constituents of seawater were $\mathrm{Ca}^{2+}$ and $\mathrm{Mg}^{2+}$ for anionic flotation. To overcome the harmful effect of these cations' soda ash was used as it minimizes collector consumption in seawater pulp. Sodium metasilicate was used to depress gangue minerals, i.e., calcareous minerals, calcite and dolomite, in alkaline circuit. The concentrate from phosphate ore was almost within the standard ratio for concentrate for acidic grade. Seawater could be used with soda ash to overcome the harmful effect of bivalent cations, saving the $7 \mathrm{~m}^{3} / \mathrm{mt}$ of fresh water.

Abuzeid et al. [50] used also the seawater (salt water) in upgrading the red sea phosphate ores. A washed low- grade phosphate stock sample was provided by the Red Sea Phosphate Company (Hamrawein area). The sample was upgraded successfully by flotation in seawater using oleate collectors, pine oil frothier, and fuel oil product (Kerosene). A phosphate concentrate assaying $31.5 \% \mathrm{P}_{2} \mathrm{O}_{5}$ at a phosphate recovery of $89.6 \% \mathrm{P}_{2} \mathrm{O}_{5}$ was obtained from a deslimed feed assaying $22.5 \% \mathrm{P}_{2} \mathrm{O}_{5}$.

\section{Abu Tartur Phosphate Ore}

\subsection{Situation and Reserves of Abu Tartur Phosphate Ore}

Abu Tartur deposits are situated in the South-Western sector of the country, in the Western Desert, $50 \mathrm{~km}$ west of El-Kharga, which is the principal town of the Kharga Oasis and the New Valley Governorate. The deposit is a part of a vast phosphorite - bearing region comprising Kharga and 
Dakhla Oases (and Abu Tartur plateau in between) and extending for more than $200 \mathrm{~km}$ latitudinally and $150 \mathrm{~km}$ meridionally. The geographical coordinates of the deposit are latitude $25^{\circ}$ $26^{\prime} \mathrm{N}$ and longitude $30^{\circ} 02^{\prime} \mathrm{E}$ as shown in Fig. (9). [1, 51].

The Abu Tartur deposit is geomorphologically localized in the South East marginal portion of Abu Tartur plateau. The plateau, $1200 \mathrm{~km}^{2}$ in area, is semi-oval in shape opening towards the N-W. In the S-E and N-W. It is limited by steep scarp. The plateau surface is formed of limestone, generally flat except for some localities adjacent to the scarp edge where some low hills and ridges composed of limestone are observed. The plateau ground elevation ranges from 450-570 m.

The phosphate ore reserves of Abu Tartur district represent about one-third of all the phosphate reserves of Egypt (more than 1000 million tons). It contains about $24.6 \% \mathrm{P}_{2} \mathrm{O}_{5}$. This ore is relatively preferred than the other Egyptian ores for the following [37, 52].

- It's better in grade and composition.

- The deposit is collected in one place and in a regular seam, having a thickness ranging between 1.5 and $4.0 \mathrm{~m}$.

- There are no underground water problems during the extraction process due to the lower underground water table in this region, compared with the other deposits such as the Red Sea deposits.

- The specifications of Abu Tartur phosphate ore are suitable for producing super phosphate, triple phosphate, and phosphoric acid. Besides, it can be used directly as a fertilizer in its fine ground form.

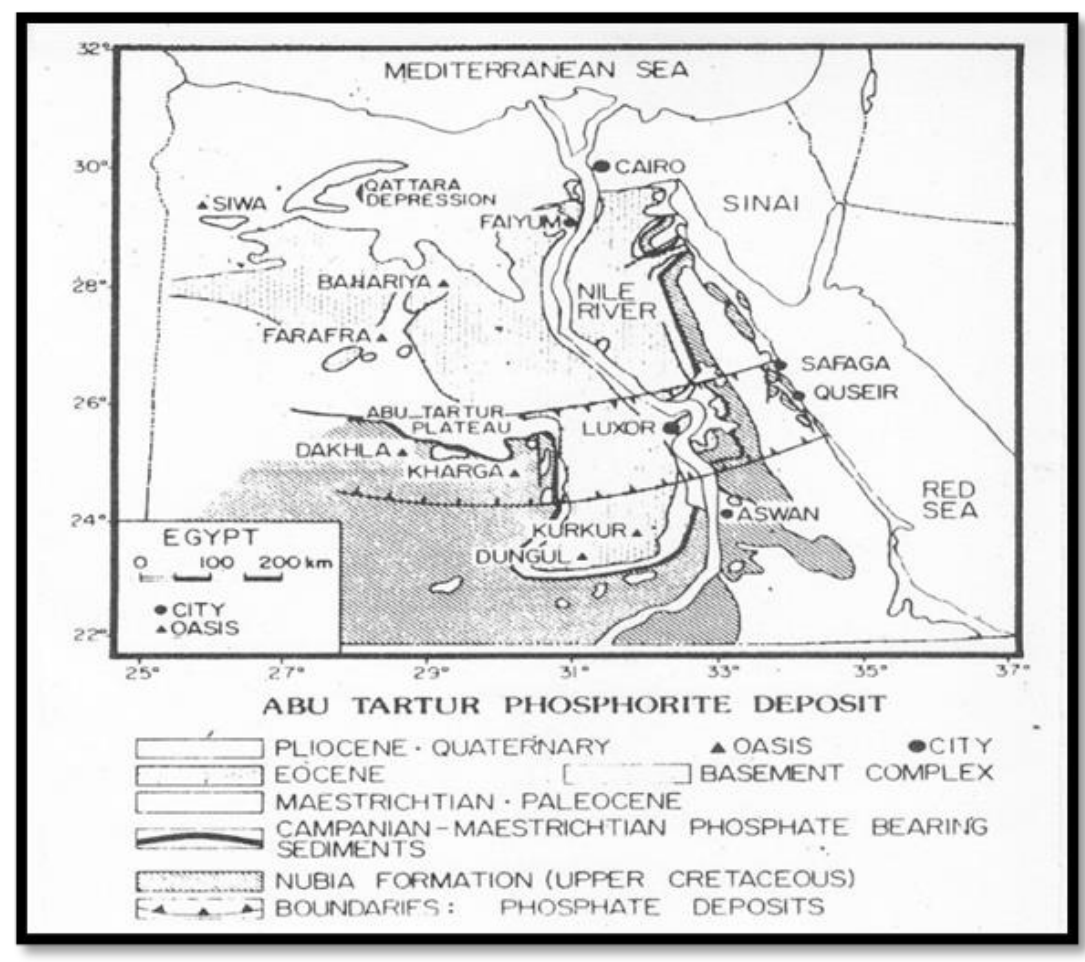

Fig. (9) Sketch map showing the general geology of central Egypt and the location of Abu Tartur Plateau [1, 51]

\subsubsection{Geology of Abu Tartur Plateau:}

Extensive phosphorite deposits of late cretaceous age occur at Abu Tartur plateau. This ore was discovered during surface geological field work by the Egyptian Geological Survey Authority in the early 1960s and various aspects of their geology have been described [53]. 
The deposits occurred in the phosphate formation which along with other cretaceous to lower tertiary units, were exposed in prominent cliffs along the Southern edge of Abu Tartur plateau and which dipping gently beneath it to the North.

At Abu Tartur, the phosphate formation is about $40 \mathrm{~m}$ thick and consists of interbedded Gray to black shales and phosphorite, glauconitic and quartz feldspathic sandstone. Measuring a section at the mine entrance shown in Fig. (10) shows that, it is convenient to divide the formation into two members. The lower member is 19 meters thick and consists of cross-bedded phosphorite sandstone with thin shale interbeds at the base and 9 meters of black grey and green-grey shale at the top. The upper member is more heterogeneous and contains interbeds of shale and sandstone of variable composition. The most prominent lithology is intensively cross-bedded glauconitic sandstone.

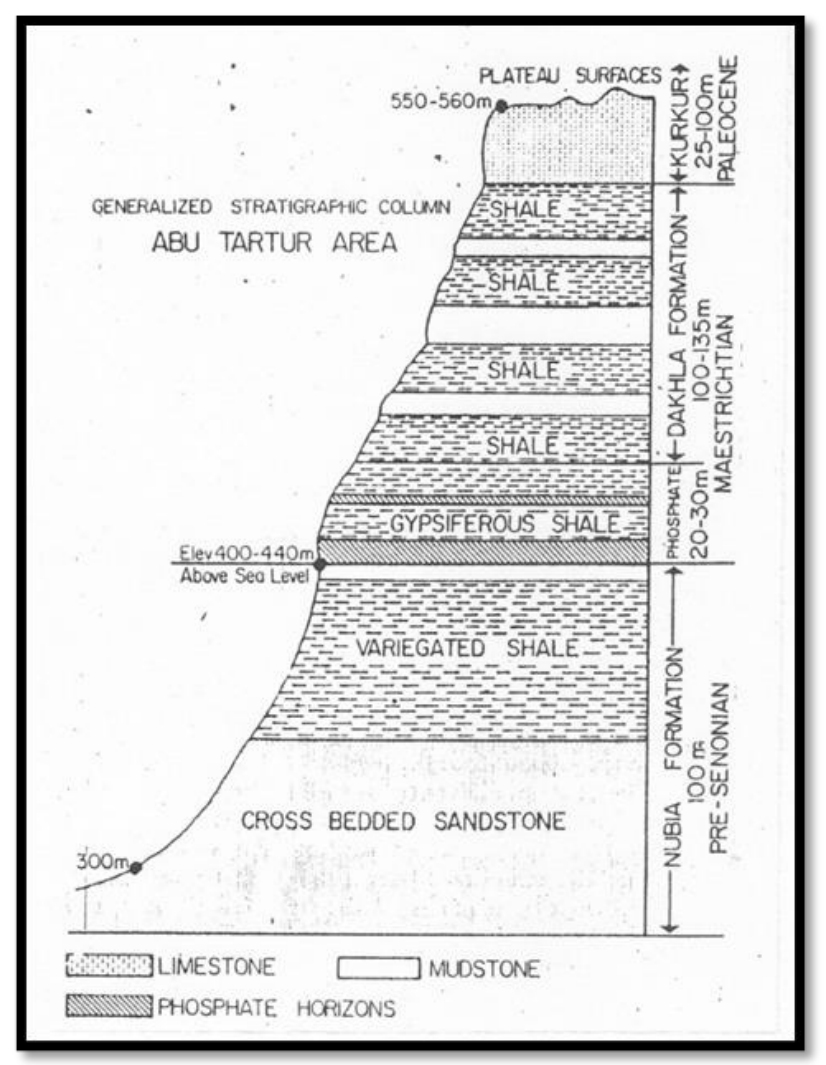

Fig. (10) Generalized stratigraphic section in the Abu Tartur area $[1,53]$

\subsubsection{Origin of Abu Tartur Phosphate ore:}

Phosphate formation was assigned to the Metricians age, which consists of grey and dark gypsiferous shales with intercalated beds of phosphorites, mudstone and glauconitic sandstone [54]. Two main phosphate members mark the phosphate formation: The lower one of an economic value and is represented by one main phosphate bed $(6-7 \mathrm{~m}$ thick). The formation is unconformably underlain by variegated sandy clays of the upper Nubia formation, and conformably overlain by rocks of the Dakhla shale. Primary phosphorites are usually dolomitic clayey, porous, dark grey to black due to the abundant carbonaceous matter and pyrite, and display a palatal texture [55]. It represents $95 \%$ of the estimated reserve. An approximate mineralogical composition of Abu Tartur deposit derived from chemical, X-ray, and petrographic data is shown in table (1) [56]. 
Table (1) An approximate mineralogical composition of Abu Tartur deposit

\begin{tabular}{|l|l|l|}
\hline \multicolumn{1}{|c|}{$\begin{array}{c}\text { Mineral } \\
\text { Component }\end{array}$} & \multicolumn{1}{|c|}{ Composition } & \multicolumn{1}{|c|}{ Weight \% } \\
\hline Apatite & $\mathrm{Ca}_{9.77} \mathrm{Na}_{0.16} \mathrm{Mg}_{0.06}\left(\mathrm{Po}_{4}\right)_{5.35}\left(\mathrm{Co}_{3}\right)_{0.65} \mathrm{~F}_{2.26}$ & 69.30 \\
Gypsum & $\mathrm{CaSO}_{4.2 \mathrm{H}_{2} \mathrm{O}}$ & 11.80 \\
Dolomite,ferrian & $\mathrm{Ca}_{1} \mathrm{Mg}_{1} \mathrm{Fe}\left(\mathrm{CO}_{3}\right)_{2}$ & 6.70 \\
Montmorillonite & $\left(\mathrm{Ca}_{0.5} \mathrm{Na}_{0.2}\right)\left(\mathrm{Al}_{2.8} \mathrm{Mg}_{0.5} \mathrm{Fe}^{2+}{ }_{0.2} \mathrm{Fe}^{3+}{ }_{0.5}\right)\left(\mathrm{Si}_{7.5} \mathrm{Al}_{0.5}\right)_{20}(\mathrm{OH})_{4} .10 \mathrm{H}_{2} \mathrm{O}$ & 3.00 \\
Geothite & $\mathrm{Fe}_{2} \mathrm{O}_{3 .} . \mathrm{H}_{2} \mathrm{O}$ & 2.70 \\
Pyrite & $\mathrm{FeS}_{2}$ & 2.10 \\
Glauconite & $\mathrm{Variable}_{2}$ & 2.00 \\
Quartz & $\mathrm{SiO}_{2}$ & 1.30 \\
Sphalerite & $\mathrm{ZnS}$ & T.R. \\
\hline
\end{tabular}

\subsubsection{X-ray Diffraction Analysis for Abu Tartur Phosphate Ore:}

The phosphate minerals, most probably fluorapatite, are the essential mineral constituents in all Xray patterns. From the results, the following main conclusions can be formulated [56-57]:

1- Dolomite was detected only in the size fraction of $-105+50 \mu \mathrm{m}$.

2- Pyrite was relatively concentrated in the size fraction of $-105+50 \mu \mathrm{m}$ followed by the size fraction of $-211+105 \mu \mathrm{m}$ and 1000 microns fraction.

3- Montmorillonite is the only clay mineral recorded.

4- Gypsum is recorded in very fine grains in the $-50 \mu \mathrm{m}$ size fraction.

On the other hand, minerals of the exogenous were detected as follows [58]

- Montmorillonite (argillaceous mineral) in the form of cement in the phosphate seam.

- Dolomite: Magnesium carbonate in the form of rhombohedrons, generally ranging between 40 and $200 \mu \mathrm{m}$ with a major part below $125 \mu \mathrm{m}$. The magnesium carbonate does not have one face only and its Fe content is probably variable and not evenly distributed in crystals.

- Quartz: found mainly below $300 \mu \mathrm{m}$.

- Sulphates: in a fibrous form frequently observable in the exogenous but in small quantity. They are more or less soluble in water.

- Pyrite and iron oxides: are rather rarely found in the form of isolated particles in the mass of ore.

- Glauconite: is an accessory mineral, organic matter an accessory constituent.

- Chlorine: probably in the form of halite (sodium chloride) was detected in small quantities in the crude ore.

\subsection{Beneficiation Technology of Abu-Tartur Phosphate Ore:}

The run of mine (R.O.M.) is delivered from the underground mines to storage area where it is screened at $60 \mathrm{~mm}$, and the oversize is crushed in a rotary crusher. The crushed ore is screened again at $60 \mathrm{~mm}$. The oversize $(+60 \mathrm{~mm})$ is discarded as its contaminated with impurities whereas the fraction below $60 \mathrm{~mm}$ is delivered to the beneficiation plant for further treatment. In the beneficiation plant, Fig. (11) the $-60 \mathrm{~mm}$ fraction is scrubbed in a $3.6 \times 10 \mathrm{~m}$ drum scrubber to 
disintegrate the ore. The scrubbed product is then screened on a $2 \mathrm{~mm}$ screen. The oversize fraction $(+2.0 \mathrm{~mm})$ is discarded due to its high dolomite content. The fraction below $2 \mathrm{~mm}$ is subjected to classification using a group of hydro cyclones to separate the clay fraction below $0.080 \mathrm{~mm}$. The latter is discharged to the main thickener of the plant as slimes. The deslimed product $(-2.0+0.08$ $\mathrm{mm}$ ) is then subjected to a second stage of washing in attrition scrubber. The product of the latter is further classified using a hydro separator, at about $0.2 \mathrm{~mm}$ into coarse and fine fractions. The coarse fraction $(-2+0.2 \mathrm{~mm})$ is filtrated and dried to decrease its moisture content to $\sim 1.5 \%$. This fraction represents the coarse concentrate.

In the meantime, the fine fraction $(-0.2 \mathrm{~mm})$ of the hydro separator is discharged to a group of hydro cyclones for further classification to separate the slimes below $0.08 \mathrm{~mm}$. The underflow of the hydro cyclones $(-0.2+0.08 \mathrm{~mm})$ is then discharged to a high intensity magnetic separator to separate the ankerite (ferrogenated dolomite) impurities as a magnetic product. The non-magnetic fraction (fine concentrate) is then subjected to filtration and drying. Both coarse and fine concentrates are blended to produce a final concentrate assaying $\sim 30 \% \mathrm{P}_{2} \mathrm{O}_{5}$ and $0.55 \% \mathrm{MgO}$. Figure (11) illustrates a suggested simplified flowsheet for beneficiation of Abu Tartur phosphate ores whereas, Table (2) shows the chemical analysis of the produced concentrates [13].

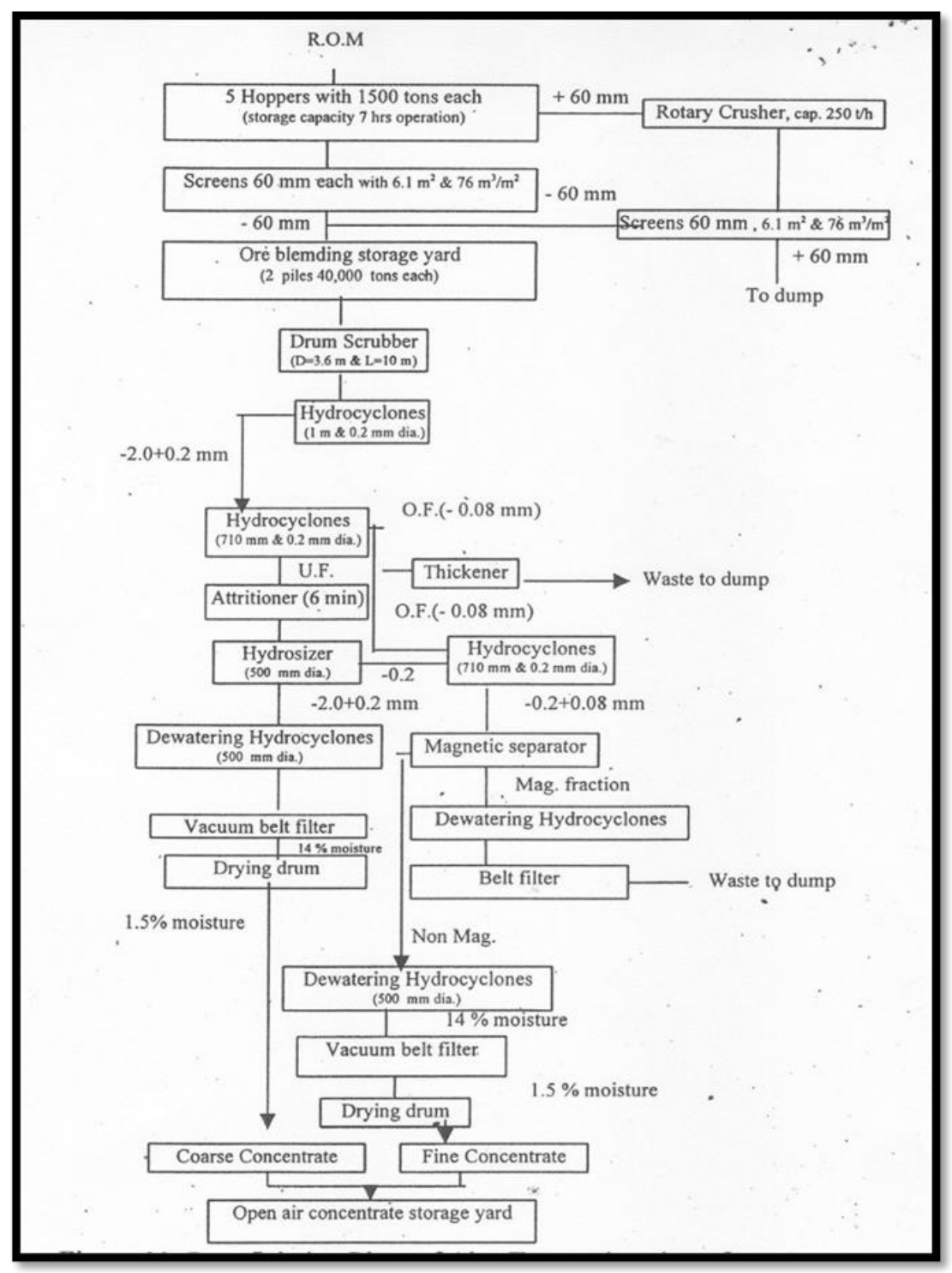

Fig. (11) Beneficiation plant of Abu Tartur phosphate ore [13] 
Table (2): Chemical analysis of Abu Tartur concentrates [13]

\begin{tabular}{|l|l|l|l|}
\hline \multicolumn{1}{|c|}{$\%$} & \multicolumn{1}{c|}{ Coarse Concentrate } & \multicolumn{1}{c|}{ Fine concentrate } & \multicolumn{1}{c|}{ Total concentrate } \\
\hline $\mathrm{Wt.}$ & 73 & 27 & 100 \\
\hline $\mathrm{P}_{2} \mathrm{O}_{5}$ & 31.2 & 30.5 & 31.0 \\
\hline $\mathrm{MgO}$ & 0.4 & 0.95 & 0.55 \\
\hline $\mathrm{Fe}_{2} \mathrm{O}_{3}$ & 3.0 & 2.5 & 2.9 \\
\hline $\mathrm{Organic}$ carbon & 0.5 & 0.5 & 0.5 \\
\hline $\mathrm{SiO}_{2}$ & 3.5 & 2.5 & 3.2 \\
\hline $\mathrm{CO}_{2}$ & 3.4 & 4.0 & 3.6 \\
\hline $\mathrm{Al}_{2} \mathrm{O}_{3}$ & 0.25 & 0.25 & 0.25 \\
\hline $\mathrm{Na}_{2} \mathrm{O}+\mathrm{K}_{2} \mathrm{O}$ & 0.95 & 0.95 & 0.95 \\
\hline $\mathrm{Cl}$ & $0.025-0.035$ & $0.025-0.035$ & $0.025-.035$ \\
\hline
\end{tabular}

\subsection{Beneficiation Trials of Abu Tartur Phosphate Ore:}

The population of Egypt will increase in the future, consequently, more water will be needed for the industry as well as irrigation of crops. Abu Ali [59] suggested three variants at a laboratory scale for beneficiation of Abu Tartur phosphate ore. The minimization of water consumption was taken into his consideration.

In general, these variants included hand picking, size reduction and dry screening. The crushed and screened ore was classified into three size fractions: $(-2000+200 \mu \mathrm{m}),-200 \mu \mathrm{m}$, while the size fraction $+2000 \mu \mathrm{m}$ was discarded. These three variants mentioned previously can be concluded as follows [59]:

1- In the first variant, the medium size fraction $(-2000+200 \mu \mathrm{m})$ was attired. Both the attired medium fraction and the fine fraction were separately deslimed using hydro cyclones to eliminate the finer sizes $<75 \mu \mathrm{m}$, which consisted mainly of clay \& dolomite and cementing material. The deslimed medium and fine size fractions were mixed together to form the product.

2- In the second variant - a, Calcination at different temperatures and varied time intervals was applied on the deslimed medium size fraction to maximize its $\mathrm{P}_{2} \mathrm{O}_{5}$ content and minimize its $\mathrm{MgO}$. On the other hand, the deslimed fine part of the ore was floated. Both concentrates received from calcination and floatation were mixed to be the total concentrate of variant II $-\mathbf{a}$.

In the second variant $-\mathbf{b}<$ all the steps in variant II $-\mathbf{a}$ was executed except that the flotation was applied on both the deslimed medium and fine fractions.

3- In the third variant. The deslimed medium size fraction and the deslimed fine fraction were classified as a mixture using a cone classifier. The overflow of the fine classifier was fed to the tabling process. The concentrate of the tabling process and the underflow of the cone classifier were collected, dried, and mixed to compose the product of variant III. The results of the three variants suggested by Abu Ali [59] are shown in Table (3). These results were compared with those obtained by Mostafa et al. [60] and Safranine [61]. This comparative study was concluded in Table (4). 
Table (3) Results of the three variants suggested by Abu Ali [59]:

\begin{tabular}{|c|c|c|c|c|c|c|c|c|}
\hline \multirow{2}{*}{ Variant } & \multirow{2}{*}{ Weight \% } & & \multicolumn{4}{|c|}{ Contents } & \multirow{2}{*}{$\begin{array}{c}\text { Net water } \\
\text { consumption } \\
\mathbf{m}^{3} / \mathrm{t}\end{array}$} & \multirow{2}{*}{$\begin{array}{c}\text { Energy } \\
\text { consumed }\end{array}$} \\
\hline & & $\mathrm{P}_{2} \mathrm{O}_{5}$ & $\mathrm{MgO}$ & $\mathrm{Fe}_{2} \mathrm{O}_{3}$ & $\mathrm{CaO}$ & I. $\mathrm{R}+\mathrm{SiO}_{2}$ & & \\
\hline I & 69.78 & 28.04 & 0.88 & 2.41 & 40.34 & 13.73 & 0.43 & Low \\
\hline II-a & 58.64 & 32.32 & 0.42 & 3.15 & 43.04 & 12.96 & 1.00 & High \\
\hline II-b & 58.96 & 32.41 & 0.49 & 3.17 & 43.93 & 12.58 & 1.20 & Very high \\
\hline III & 62.08 & 30.77 & 0.43 & 2.56 & 41.54 & 13.38 & 0.60 & medium \\
\hline
\end{tabular}

Table (4) Comparative study between suggested variants [59], Mostafa etal [60] and So remine [61-62]

\begin{tabular}{|c|c|c|c|c|c|c|}
\hline $\begin{array}{c}\text { Variant } \\
\text { No. }\end{array}$ & Main process & $\mathrm{P}_{2} \mathrm{O}_{5} \%$ & $\begin{array}{c}\text { Net water } \\
\text { consumption } \\
\mathbf{m}^{3} / \mathrm{t}\end{array}$ & $\begin{array}{c}\text { Energy } \\
\text { consumed }\end{array}$ & $\begin{array}{c}\text { Capital } \\
\text { cost }\end{array}$ & $\begin{array}{l}\text { Uses of the } \\
\text { product }\end{array}$ \\
\hline $\mathrm{I}$ & Desliming & 28.06 & 0.43 & Low & Low & Super phosphate \\
\hline II-a & $\begin{array}{l}\text { *Desliming } \\
\text { *Calcination } \\
\text { *Flotation }\end{array}$ & 32.32 & 1.00 & High & High & $\begin{array}{l}\text { Triple phosphate } \\
\text { Phosphoric acid }\end{array}$ \\
\hline II-b & $\begin{array}{c}* \text { Desliming } \\
* \text { Calcination } \\
\end{array}$ & 32.14 & 1.20 & Very High & $\begin{array}{l}\text { Very } \\
\text { High }\end{array}$ & Triple phosphate \\
\hline III & $\begin{array}{c}* \text { Desliming } \\
\text { *Classification } \\
\text { *Tabling } \\
\end{array}$ & 30.84 & 0.60 & Medium & Medium & Triple phosphate \\
\hline $\begin{array}{c}\text { IV } \\
\text { (Mostafa et } \\
\text { al) } \\
\end{array}$ & $\begin{array}{l}* \text { Flotation } \\
* \text { Wet HIMS }\end{array}$ & 31.20 & - & High & High & Triple phosphate \\
\hline $\begin{array}{c}\mathrm{V} \\
\text { (So remine) }\end{array}$ & $\begin{array}{c}* \text { Classification } \\
* \text { Wet HIMS }\end{array}$ & 31.50 & 1.50 & High & High & Triple phosphate \\
\hline
\end{tabular}

Considerable work has been carried out in Egypt and abroad to search for an efficient process to beneficiate Abu Tartur phosphate ore [62-63]. The major difficulties arise from the presence of unoxidized carbonate, clay, glauconite and pyrite. These phases are extremely finely disseminated and inter-grown with phosphate. Conventional methods of washing, flotation and calcination were not very unsuccessful in raising $\mathrm{P}_{2} \mathrm{O}_{5}$ content and failed to remove the harmful iron and Sulphur phases which characterize the Abu Tartur deposits. Attempts were made by Safranines [62] to apply a very rapid increase of temperature (at $800^{\circ} \mathrm{c}$ or $900^{\circ} \mathrm{c}$ ) to turn pyrrhotite into magnetite. Thus, the phosphate produced had a high content (Fe 2.68\%). A process combined crushing, screening, hydraulic classification, low temperature roasting $\left(650^{\circ} \mathrm{C}\right)$ and dry high-intensity magnetic separation was found to give more satisfactory results than those attained by flotation and calcination of Abu Tartur ore [63].

Gocke and Jacob [64] concluded that, by selective grinding and thermic pre-treatment at $400^{\circ} \mathrm{c}$, as well as by classification and high voltage magnetic separation, it was possible to produce a phosphorite concentrate with $32.2 \% \mathrm{P}_{2} \mathrm{O}_{5}$ and a pre-concentrate with $29.8 \% \mathrm{P}_{2} \mathrm{O}_{5}$, both having a low pyrite content. The by-product obtained was pyrite concentrate with $32.9 \% \mathrm{FeS}_{2}$. The yield of phosphorite amounts $84.3 \%$ maintaining the relation concentrate/preconcentrate $=2.6$. The yield of iron relative to the total contents is $61.5 \%$. It was proved that, the concentration produced is suitable as a base material for manufacturing a raw phosphate fertilizer. They evaluated the power consumption by $25 \mathrm{kwh} / \mathrm{t}$. On the other hand, Nancy Univ. [65] advised to stop the dry methods for beneficiation of Abu-Tartur ore, as these methods could not recover the pyrite. Abu-Tartur phosphate rock was adapted to the hydrate process in a single tank reactor. The concentrated phosphoric acid, from which the two most important phosphatic fertilizers, triple super phosphate and diammonium phosphate ore were produced, while taking advantage of utilizing the by-product phosphogypsum for reclamation of barren soil for revegetation [66]. 
Youssef et al. [67] suggested a simplified technique to improve the chemical reactivity of Abu Tartur phosphate ores to meet the specifications required for direct applications as a natural fertilizer. This technique was based on heating the ore in a sintering machine with coke breeze and some additives such as soda ash or glass. The reactivity of the sintered product was increased with increasing the percent of such additives. A new extraction system for the removal of iron from monocalcium/phosphoric acid aqueous solution was suggested using ternary solvent and tri-n-octyl amine as a liquid anionic extractant by Sami et al. [68]. This system showed high efficiency in the removal of iron from phosphoric acid/phosphate salt solution to reach more than $77 \%$ extraction using different aqueous/organic ratio.

The amenability of upgrading the rejection from beneficiating Abu-Tartur phosphate ore by magnetic separation was investigated by leaching with acetic acid solutions and froth flotation [69]. The reject was characterized by its ferriferous dolomite impurities. The results of the leaching process gave unsatisfactory results. Adversely, the experimental results of flotation have shown that it was possible to obtain phosphate concentrate assaying $30 \% \mathrm{P}_{2} \mathrm{O}_{5}$ and $0.75 \% \mathrm{MgO}$ with $\mathrm{P}_{2} \mathrm{O}_{5}$ recovery of about $75 \%$ from a feed assaying $23 \% \mathrm{P}_{2} \mathrm{O}_{5}$ and $3.77 \% \mathrm{MgO}$. An investigation was conducted to recover the phosphate values from the tailing's thickener of Abu Tartur pilot plant by Abdelrahman [70]. Hydro cyclone and flocculation techniques were used to recover the phosphate values and to enhance the dewatering rate of the phosphatic clay waste. The hydro cyclone separation produced an underflow fraction rich in phosphate values and an overflow fraction rich in clays. The former represented $39.8 \%$ of the waste and assayed $26 \% \mathrm{P}_{2} \mathrm{O}_{5}$, from a feed of $15.57 \%$ $\mathrm{P}_{2} \mathrm{O}_{5}$, at a recovery of $66.36 \%$. The results of the flocculation of the phosphatic clay waste indicate that the settling rate were increased and the process water could be recycled. The settling rate of the waste was 37 times greater than its natural settling rate when anionic polyacrylamide (A130) was used.

Abuzeid et al. [10] reviewed some of the published work on the separation of carbonates from different origins of phosphate ores by flotation and compared the flotation results of phosphate ore samples different in their physical properties and mineralogical compositions. These results reflected the effect of ore nature on the flotation performance and the reagents consumption. The samples were from El-Hamrawein (Red Sea Coast), East Mahamid (Nile Valley), East Sebaya (Aswan), and Abu Tartur (New Valley). Abdel-Khalek et al. [71] applied the bio-flotation technique on samples of single minerals of quartz and apatite of high purity to obtain the optimum conditions. Using the same optimum conditions on the flotation of New Valley Egyptian phosphate ore, a concentrate containing $30 \% \mathrm{P}_{2} \mathrm{O}_{5}$ and $10 \% \mathrm{SiO}_{2}$ with $68 \%$ recovery was obtained from a feed containing $20.52 \% \mathrm{P}_{2} \mathrm{O}_{5}$ and $23.51 \% \mathrm{SiO}_{2}$.

\section{Summary and Recommendations}

- Considerable effort has been made during the last three decades to develop and improve the upgrading strategies of the Egyptian phosphate ore.

- It is recommended to use a cheap fuel such as natural gas as a source of energy to reduce the calcination costs of the Egyptian calcareous phosphate ore.

- A great deal of attention should be paid to recover phosphate from its slimes which requires the use of modern technologies such as column flotation as well as the new types of reagents that appear in the market nowadays.

- Further research work in the application of bio-flotation process using the different microorganisms as a new technique to upgrade the dolomitic phosphate is needed. 
- High-grade ore reserves are going to deplete at an accelerating rate. Thus, the re-exploitation of the rejected fine tailings and the use of the low-grade ores should attract the attention of researchers.

- Large quantities of coarse phosphate solid wastes are produced as a result of phosphate beneficiation processes. Therefore, more research work to exploit these wastes in concrete production, road constructions and as a replacement soil under foundations should be studied.

- The shortage of fresh water will be the problem of the forthcoming years. Therefore, more attention should be paid to minimize water consumption in ore dressing plants.

- Selective mining should be avoided, especially for big projects that have large quantities of ore. This behavior will lower the beneficiation costs of the ore.

\section{References}

[1]. Elmaadawy, Kh.G., Ezz El Din, M., Khaled, A.M., and Abozeid, A-Z. M., "Mineral industry in EgyptPart II Non-metallic commodities phosphate rocks". Journal of Mining World Express (MWE), Vol.4 (2015), pp.1-18.

[2]. Jasinski, S.M. (2014)." Phosphate rock", USGS, 118.

[3]. Mohammad Khani, M., Noparast, M., Shafaei, S. Z, Amini, A., and Abdollahi, H., "Double reverse flotation of a very low-grade sedimentary phosphate rock, rich in carbonates and silicates", Int.J. Min.Process., 100 (2011), pp.157-165.

[4]. Charbagh, M., Nacarats, M., and Iranian, M., "Selective leaching Kinetics of lower grade calcareous phosphate ore in acetic acid" Hydrometallurgy, Vol.95 (2009), pp.341-345.

[5]. Abdel-Zaher, M.A., "Physical and thermal treatment of phosphate ores-an overview Int.J. Miner.Process, 85 (2008), pp.59-84.

[6]. Jasinski, S.M., "phosphate Rocks", USGS, (2007), pp.120-121.

[7]. Guimaraes, R-C., and Araujo, A.C., "Reagents in igneous phosphate ores flotation", Miner.Eng, 18 (2005), pp.199-204.

[8]. Emich, G.D., "Phosphate rocks", Ind. Miner. Rocks 2 (1984), pp.1017-1047.

[9]. Sengul, H., Kadir Ozer, A., and Sahin Gulaboglu, M., "Beneficiation of Mardin Mazida (Turkey) calcareous phosphate rock using dilute acetic acid solutions", Chem. Eng. J., 122 (2006), pp.135-140.

[10]. Abouzeid, A-Z.M., Negm, A.T., and Elgillani, D.A., "Upgrading of calcareous phosphate ores by flotation: effect of ore characteristics", Int. J. Miner. Process, 80 (2009), pp.81-89.

[11]. Ellgillani, D.A., and Abouzeid, A-Z. M., "Flotation of carbonates from phosphate ores in acidic media", Int. J. Miner. Process, 38 (3-4) (1993), pp.235-256.

[12]. Herninz, F., Calero, M., and Blazquez, G., "Flotation of low-grade phosphate ore", Adv. Powder Technol., 15 (4), (2004), pp.421-433.

[13]. Abdel-Khalek, N.A., "Recent trends in phosphate beneficiation technology - A Review Article, CMRDI, Cairo, Egypt, (2000).

[14]. Austromineral, El-Nasr Phosphate Co., International Report, (1999).

[15]. Griffiths, J., "Phosphate rock prevailing climate uncertain", Industrial minerals, March (1994), pp.4763.

[16]. Boulos, T.R., Boulis, S.N., and Abdel-Khalek, N.A., "Investigation performance of the phosphate beneficiation plant of Sebaiya West", Report from CMRDI presented to Abu Zaabal fertilizer and Chemical Co., (1990).

[17]. Boulos, T.R., and Abdel-Khalek, N.A., and Ibrahim, S.S., "Improving the settling rate of the phosphate slimes at Sebaiya West", Report from CMRDI presented to Abu Zaabal fertilizer and Chemical Co., Cairo, Egypt (1991).

[18]. Abdel-Khalek, N.A., "Evaluation of flotation strategies for sedimentary phosphates with siliceous and carbonates gangues", Mineral Engng., Vol.13, No.7 (2000), pp.787-793. 
[19]. Abdel - Khalek, N.A., Ibrahim, S.S., and Boulos, T.R., "Flotation of phosphate slimes by different types of polyacrylamides", Al-Azhar Engineering Second International Conference, Cairo, 21-24, Dec. (1991).

[20]. Ibrahim, S.S., and Abdel-Khalek, N.A., "The action of different types of corn starch on the flocculation of phosphate slimes", Mineral Engng., Vol.5, No.8, (1992), pp.907-916.

[21]. Negm, A.A., and Abuzeid, A-Z., M., "A general outlook on the technology of preparation and concentration of ores in Egypt", J. of Techn., Egyptian Syndicate of Engineers, Vol.1, No.1, (1994).

[22]. Abuzeid, A-Z.M., Raghi, S.M., Abu-Elsaadat, M.M., Abudul Majeed, A.A, and Rizk, A.M., "Maximizing the added value of the Egyptian mineral ores - A round table discussion", $9^{\text {th }}$ Int. Conf. on Mining, Petrol., and Metall. Conf., Cairo Univ,21-24 Feb. (2005).

[23]. Tarshan, M.M., "Calcination of phosphate ore in fluidized bed", MSc thesis, Mining and Metall. Engng. Dept., Faculty of Engng., Assiut University, Feb. (1977).

[24]. Yousef, A.A., El-Nozahi, S.M., and Ali, N., "Some aspects on the calcination and quenching of Sebaiya East phosphate", Aufbereitungs - Technik, No.2 (1986), pp.94-99.

[25]. Abd El-Reihem, F.H., "Some aspects on the flotation of fine particles with special emphasis in Egyptian phosphate and kaolin ores", Ph.D. Thesis, Faculty of Science, Ain Shams University, Egypt, (1997).

[26]. Ramadan, A.M., "Flotation studies on processing phosphate ore from El-Sebaiya East, Egypt", CIM Journal, Vol.5, No.4 (2014), pp.221-226.

[27]. Negm, A.A., and Emam, E.H., "Management of phosphate slime tailings", The Third Mining Petroleum and Metall. Engng. Conference, Cairo University 2-4, Feb. (1992), Vol.1 (Mining Engng), pp. 320-330.

[28]. Negm, A.A. and Abuzeid A-M., "Application of mineral processing technology for environmental protection and recycling", The Fifth Int. Conf. on Petroleum, Mining and Metall.Eng., Suez Canal University, Suez, Egypt, 24-26 Feb. (1997), pp. 127-145.

[29]. Down, C.G, and Stocks, J., "Environmental problems of tailings disposal", Mining Magazine, July (1977), pp.25-33.

[30]. Hill, R.D. and Aurbach, J.L., "" Solid waste disposal in the mining industry" Proc. of the Int. Symp. Of Fine Particles Processing, Editted by Sumasundaran, Vol.2 (1980), pp.1731-1753, Las Vegas, Nevada, 24-28 Feb.

[31]. Ismail, A.K., "Novel solutions of environmental problems of Egyptian phosphate industry", Journal of Egyptian Society for Engineering and Metallurgical Industries, No.5 (1995), p.38.

[32]. Himida, M.M., "A study on the possibility of using phosphate mill tailings of some Egyptian phosphate mines", MSc. Thesis in Mining Engng., Mining and Metall. Engng. Dept. Faculty of Engng., Assiut University, (1999).

[33]. Galal, A. I., Abdul-Majeed, A., Rizk, A.M.E., and Hemida, M.M., "A positive use of El Sebaiya phosphate tailings", Bulletin of the Faculty of Engng., Assiut University, Vol.27, No2, July (1999).

[34]. Rizk, S.A., "An experimental study on utilization of solid wastes generated from phosphate ore processing and ornamental stones quarrying as coarse aggregate in civil constructions", $\mathrm{PhD}$. Thesis, Mining and Metall. Engng. Dept., Faculty of engng., Assiut University, (2015).

[35]. Abuel kasem, M., Abdel Azim, G., Rizk., A., Ahmed, M.M, Nozahy, A., Abdel-Khalek, N.A-and Bakheat, H., "Upgrading of phosphate ore wastes of El-Nasr Mining Company, Egypt", Int. J. Mineral Process. And Extractive Metall., Vol. 3, No. (2), (2018), pp.37-46.

[36]. Abuel Kasem, M., Abel Azim, G., Rizk, A., Ahmed, M.M., Nozahy, A., Abdel-Khalek, N.A. and Bakheat, H., "Economics of exploitation phosphate ore wastes", Int. J. of Mining Engng. And Mineral Process. Vol.7, No. (1) (2018), pp.14-20.

[37]. Abdel-Khalek, N.A., "Beneficiation of some Egyptian calcareous phosphates", MSc thesis, Ain Shams University, (1982).

[38]. Youssef, A.A. (P.I.), "Beneficiation of El-Hamrawein phosphate ores", Final Report, CMRDI, Cairo, Egypt, (1980). 
[39]. Orphy, M.K., Youssef, A.A., and Hanna, H.S., "Beneficiation of low-grade phosphate ore, Part I", Mining and Minerals Engng., May (1968), pp.44-50.

[40]. Orphy, M.K., Youssef, A.A., and Hanna, H.S., "Beneficiation of low-grade phosphate ore, Part II": Cationic flotation of silica from phosphates", Mining and Minerals Engng., Oct. (1968), pp.48-54.

[41]. Bibawy, T.A., and Yousef, A., "Inverse anionic flotation of Egyptian dolomitic phosphate ores", Aufbereitungs Technik, No.5 (1983), pp.262-269.

[42]. Abdelrahman, A.A., "Beneficiation of phosphate rock by flotation", The Fourth Mining, Petroleum and Metall. Engng. Conference, Assiut University 5-7 Feb. (1994).

[43]. Abdul-Majeed, A., "Upgrading of Qusseir low grade calcareous phosphate ore by leaching process", Bulletin of the Faculty of Engng., Assiut University, Vol.24, No.2, July (1996), pp.135-140.

[44]. Rizk, S.A., "A comparison study between calcination and leaching of calcareous phosphate ore", Bulletin of the Faculty of Engng., Assiut University, Vol.47, No.3, March (2019).

[45]. Ramadan, A.M., "Upgrading of Hammrawein phosphate ore by flotation", MSc thesis, Al-Azhar University, Faculty of Engng, Mining and Petol. Dept, (1991).

[46]. Suzan, S.I., Khaled, E.Y., and Tawfik, R.B, "Processing of East Mediterranean Phosphate ore sample by an integrated attrition scrubbing classification scheme Part: 1", Separation Science and Technology, Jan, (2019).

[47]. Suzan, S.I., Khaled, E.Y., and Tawfik, R.B, "Processing superfine and ultrafine phosphate, of a phospho - mud Part II", Environmental and Natural Resource Research Journal, Vol.9, No.2, (2019), pp.102-115.

[48]. Yehia, A., Yassin, K.E., and Amar, A, "Upgrading of phosphate fines by fatty acid flotation using amylase enzyme as a surface modifier", Mining, Metallurgy, and Exploration, 36 (2019), pp.949-955.

[49]. Yousef, A.A., Arafa, M.A, Ibrahim, S.S., and Abdel Khalek, N.A., "Sea water usage in flotation of mineral beneficiation in Arid Regions".

[50]. Abozeid, A.M., Negm, A.A., and Seif El Nasr, A.A.S., "Upgrading of Hamrawein low grade phosphate stock using sea water", The Third Int. Conference on Mining, Petroleum and Metall. Engng., Cairo University, Vol. I, Feb. (1992), pp.311-319.

[51]. Wassef, A.S., El Shafey, S.B., Taha, F., and Bahr, W.H., "The laboratory technical tests of phosphate ore from Abu Tartur deposit", ANNALS of the Geological Survey of Egypt, Vol.VII, (1977), pp.6188.

[52]. Mc Cune, D.L., "Evaluation of Abu Tartur phosphate materials for manufacture of selected phosphate fertilizers", (IFDC) Muscle Shoals, Alabama, May (1980).

[53]. Kammel, O.A., "Origin of the Egyptian phosphates", Annals of the Geological Survey of Egypt, Vol. VII, (1982), pp.237-254.

[54]. Dardier, A.A., "The mineral resources base of Egypt-Invited Talk", $2^{\text {nd }}$ Int. Conf. On Geology of Africa, Assiut University, 28-30 Oct. (2001).

[55]. Garrison, R.E., "Sedimentary and origin of upper cretaceous phosphorite deposits at Abu Tartur Western desert, Egypt, Annals of the Geological Survey of Egypt, Vol. IX, (1979), pp.261-281.

[56]. Neft Chimpromexport, "Feasibility report on developing the phosphate deposits of Abu Tartur in A.R.E.", Moscow, (1972).

[57]. Yossif, A.A., "Laboratory wet beneficiation tests", National Research Center, Cairo, March (1979).

[58]. Sofremine, "New Valley phosphate project appraisal report", Iron and Steel Comp. (1977), pp.1-70, and Section III, July (1980).

[59]. Abu Ali, M.H., "Beneficiation of Abu Tartur phosphate ore with reference to the minimization of water consumption", MSc Thesis, Mining and Metall. Engng. Dept., Faculty of Engng., Assiut University, (1987).

[60]. Mostafa, S.N., Abu Gharib, E.A., and Dardir, A.A, "Beneficiation of Abu Tartur phosphate ores" Annals of the Geological Survey of Egypt, Vol X, pp.1069-1085, (1980).

[61]. Sofremine-Alusuisse, "New Valley phosphate project Abu Tartur" Sec. III, Vol.2, July (1982).

[62]. Sofremines, Complementary beneficiation tests on Abu Tartur phosphate rock, France (1975). 
[63]. Cohen, E., and Hamoud, N.S., "Low temperature roasting in upgrading the non-oxidized phosphates of Abu Tartur Plateau (Western Desert, Egypt)" XIII International Mineral Processing Congress, Warsaw, Vol. II (1979), pp.533-555.

[64]. Gock, E., and Jacob, K.H., "Conceptions for the pyrite-bearing phosphorite of Abu Tartur", Berlin University (1984).

[65]. Nancy University Report, (1975).

[66]. Estfan, S.F., and Abdalla, F.H.A, Basily, A.B., and Hewaidy, F., "Chemical processing of Abu Tartur phosphate rock", Aufbereitungs Technik, No.4, (1986).

[67]. Youssef, M.A., Abdel Khalek, N.A., Ebrahim, E., Mohamed, O.A. and Shalabi, M.E.H., "Adaptation of the sintering technique for production of high reactive phosphates for using as natural fertilizer", the Third Int. Conference on Mining. Petroleum and Metall. Engng., Cairo University, Vol.1, 2-4 Feb. (1992), pp.292-300.

[68]. Sami, T.M., Abdel Tawab, S.A., and Sayed, S.A., "Extraction of iron from Abu Tartur phosphate aqueous leachate solution", The Fourth Int. Conference on Mining Petroleum and Metall. Engng., Assiut University, 5-7 Feb (1994), pp.244-250.

[69]. Seifelnasr, A.A.S., and. Adul-Majeed. A., A., "Enrichment of Abu Tartur phosphate ore wastes" Bulletin of the Faculty of Engng., Assiut University, Vol.26, No.1, Jan. (1998).

[70]. Abdelrahman, M.K., "Recovery of phosphate values, and flocculation of phosphatic clay waste from Abu Tartur, Egypt", Trans. Instn. Mining. Metall. (Sec. C: Mineral Process. Extr. Metall.), (1999), pp.C115-C120.

[71]. Abdel khalek, N.A., Selim, K.A., Yassin, K.E., and Abdallah, S.S., "Bio-Flotation of Egyptian phosphate using Desulfvibrio desulfuricans Bacteria", Journal of Mining World Express (MWE), Vol.4, (2015), pp.19-26. 